\title{
Legal Aspect of Relationship between Political Parties, People, and People's Representatives
}

\author{
Dwi Putri Cahyawati and Zainal Arifin Hoesein
}

\author{
Faculty of Law Universitas Muhammadiyah, Jakarta 15419, Indonesia
}

\begin{abstract}
This article discussed the topic of political party membership in the Indonesian Parliament institutions, which is based on the pattern of relations between the People's Representatives and the people they represent, and their impact in the process of forming and implementing strategic policies that rely on popular sovereignty. The article focused on the study of politics of law in the institutionalization of political parties within the parliament's institutions and the impact on the exercise of popular sovereignty. This paper has several different approaches if related to the basic theory of democracy about political links which generally examines the relationship between political parties and their voters, between politicians and citizens, and between members of parliament and their people. The results emphasize the pattern of relations between the representatives of the people and the people they represent, in connection with the institutional existence of the Indonesian parliament which is the executor of people's sovereignty.
\end{abstract}

Keywords: Legal Relationship, Political Parties, People's Representatives, Indonesia.

\section{INTRODUCTION}

Article 1 Paragraph (2) of the 1945 Constitution of the Republic of Indonesia, which affirms the existence of the highest authority in the hands of the people and its implementation is by the formulation in the Constitution, shows that the people as holders of sovereignty in a State must abide by the things specified in the Constitution. The statement also contained the meaning, that one form of people's sovereignty in the Basic Law is attached to the House of Representatives (hereinafter referred to as the DPR).

Sociologically, the existence of the DPR as a people's representative is a mandate from all Indonesian people that must be carried out. In its position as a representative of the people in the DPR's institutions, the relationship between the people and the DPR (the relationship between the people's representatives and the parties represented) is more of a mandate that must be carried out, especially related to the implementation of DPR functions. In connection with this, the DPR should be responsive in responding to various demands in society, and not prioritizing the interests of the political parties that carry them.

In the practice of Indonesian state administration, the role of the DPR as a representative institution of the people is manifested in the form of factions, which are an extension of political parties and DPR institutions. In this case, the faction was formed to optimize the functions, duties, and authority of the DPR.

*Address correspondence to this author at the Faculty of Law Universitas Muhammadiyah, Jakarta, JI. KH Ahmad Dahlan, Cirendeu, Ciputat Timur, Jakarta 15419, Indonesia; Tel: (021) 7490385; Fax: (021) 7432590;

E-mail: zainalhoesein.umj@gmail.com
This article will discuss the topic of political party membership in the DPR RI institutions, which is based on the pattern of relations between the people's representatives (DPR) and the people they represent, and their impact in the process of forming and implementing strategic policies that rely on popular sovereignty. This writing will focus on the study of legal politics in the institutionalization of political parties within the DPR's institutions and their impact on the exercise of popular sovereignty.

This paper has several different approaches if related to the basic theory of democracy about political links which generally examines the relationship between political parties and their voters (Merkl \& Lawson, 1988), between politicians and citizens (Kitschelt, 2000), and between members of parliament and their people (Stokke \& Törnquist, 2013).

However, this paper emphasizes the pattern of relations between the representatives of the people and the people they represent, in connection with the institutional existence of the DPR which is the executor of people's sovereignty.

At the ideal level, every legislative member should carry the sovereignty of his constituents. The people's sovereignty cannot be ruled out by anyone, but, members of the legislature who have the same party background and are grouped according to their party, can weaken or even override people's sovereignty, if the actions of the party members integrated into the DPR's membership are not in line with the party's wishes, even if they serve as the head of a political party, they still have to be more subject to the rules that have been set by political parties, otherwise, political parties can easily withdraw or dismiss them from 
political party membership (Pradityo, 2018). This of course can automatically eliminate his position as a member of the legislature. This picture has often occurred through a mechanism of recall or dismissal based on the original party's proposal. Such practices result in the shifting of people's sovereignty to political party sovereignty, because in fact against violations of popular sovereignty there is no direct mechanism to impose sanctions, usually only moral and political sanctions or only have an impact on popularity whereas if they conflict with party policies will result in a fatality (Bünte \& Ufen, 2008).

Based on the explanations that have been put forward, it can be seen, that the existence of political party membership in the DPR institutions has an impact on the unfulfillment of the objective of the House of Representatives as an extension of the people it tends to give birth to policies that are not oriented towards popular sovereignty. The configuration built in the body of the DPR is more of an authoritarian political configuration, resulting in conservative/orthodox legal products, as well as in carrying out other functions of the DPR.

In this regard, it is very interesting that the membership of political parties in the DPR is analyzed in more depth, especially about its existence as a representative body of the people, which even though it originates from a political party, is "considered a people's representative".

\section{DEMOCRATIC ELECTIONS AND THE CONSTITUENCY}

Democracy which is better known as governance from the people, by the people, and for the people is the most qualified model of state administration. The existence of Indonesia as a democratic state is guaranteed in the provisions of Article 1 paragraph (2) of the 1945 Constitution of the Republic of Indonesia, which states that "sovereignty is in the hands of the people and implemented according to the Constitution". This means that the people as the highest authority in the country are subject to the mechanism of the Constitution, which mandates their sovereignty to the people's representative institutions.

Related to the implementation of people's sovereignty, to be able to realize the people's sovereignty with representation. The DPR as an institution representing the people turned out to be a representation of members of political parties. This is illustrated in the provisions of Article 22 of the 1945 Constitution of the Republic of Indonesia, which requires that the general election participants to elect DPR members are political parties so that it can be interpreted, that only political party members can become DPR members. On this basis, the provisions in Article 240 Paragraph (1) of Law Number 7 of 2017 concerning General Elections were born, which then determine the requirements to become prospective candidates for the DPR member (Ulum, 2019).

The formulations carry the consequence of dual membership in the DPR. On the one hand, members of the DPR elected in general elections are referred to as people's representatives who are expected to represent the people in implementing their sovereignty. But on the other hand, the DPR member is the representative of the political party that carries it. This condition will certainly greatly affect the performance of DPR members.

Political parties have power in the legislative body, because political parties may impose their aspirations through their representatives in the DPR. As a result, members of political parties who are also members of the DPR have limitations in conveying various aspirations that arise both their aspirations and the aspirations of the people.

In the context of such a system of people's representation, political parties within the DPR are grouped into several factions. The existence of these factions is then expected to become an extension of political parties with the DPR. Through these factions, political parties can monitor the performance of their members in the DPR. This can result in the lack of attention of members of the DPR towards their constituents because DPR members are more concerned with the aspirations or interests of their political parties rather than the aspirations or interests of constituents who have mandated the mandate of the people's sovereignty to him.

The existence of factions is formulated expressly in Article 82 of Law Number 2 of 2018 concerning the Second Amendment to Law Number 17 of 2014 concerning the MPR, DPR, DPD, and DPRD which formulated that faction is a grouping of members based on the configuration of political party members resulting from the general election. Every member of the DPR must be a member of a faction. A faction formed by political parties that meet the threshold of vote acquisition in determining the acquisition of seats in the 
DPR. Faction is formed to optimize the implementation of the functions, authority, duties of the DPR, as well as the rights and obligations of DPR members. The faction is supported by the secretariat and experts. The DPR's Secretariat General provides facilities, budgets, and experts for the smooth running of the faction's tasks. Further provisions regarding the facilities and experts of the factions as referred to in paragraph (6) shall be regulated in a DPR Regulation.

Provisions regarding the factions are also formulated in Article 20 and Article 21 of the Regulation of the House of Representatives of the Republic of Indonesia Number 2 of 2018 concerning the Third Amendment to the Regulation of the House of Representatives of the Republic of Indonesia Number 1 of 2014 concerning the Standing Orders, which formulate, that faction is formed to optimize the implementation of the functions, authority, and duties of the DPR, as well as the rights and obligations of Members. Faction formed by political parties that meet the threshold of vote acquisition in determining the acquisition of seats in the DPR. The faction may also be formed by a combination of 2 (two) or more political parties as referred to in paragraph (2). Each Member must be a member of one of the factions. The faction is tasked with coordinating the activities of its members in carrying out the authority and duties of the DPR as well as increasing the ability, discipline, effectiveness, and work efficiency of its members in carrying out the tasks reflected in each DPR's activities. The faction evaluates the performance of its members and reports to the public at least 1 (one) time in 1 (one) session year. Faction leaders are determined by their respective factions. Faction forms internal work procedures by statutory provisions.

Moreover, in Article 21, it is stated that the faction is supported by the secretariat and experts. The Faction Secretariat is determined by the Secretary-General of the DPR with the approval of the leadership of the faction. Experts in each faction shall at least several DPR equipment and receive additional proportional based on the number of members of each faction. The recruitment of Faction experts is carried out by the leadership of the Faction and the results of the recruitment are conveyed to the Secretary-General of the DPR to be determined by a Decree of the Secretary-General of the DPR. The recruitment of Faction experts as referred to in paragraph (4) is based on expertise competencies determined by the leadership of the Faction. The Faction submits the budget and the needs of the Faction's secretariat and experts to the Household Affairs Agency. The Household Affairs Agency shall forward the Faction's proposal as referred to in paragraph (6) to the Secretary General of the DPR for further action.

\section{POLITICAL PARTIES AND PEOPLE ASPIRATION}

Following its role and function as a channel for the aspirations of the people, political parties have several functions that can support the implementation of people's sovereignty. The main function of political parties is as a means of political recruitment. In this case, political parties play a role in recruiting candidates for the DPR who will be proposed in the general election. This then created a relationship between political parties, the people, and the House of Representatives.

The mechanism starts from the proposals of political parties against candidates for the DPR, which are then directly elected by the people as the holders of people's sovereignty. Candidates for DPR members who have met the requirements and who have been elected to become DPR members will then represent the people in the process of running the country

Another function of political parties is as a means of political communication, namely channeling diverse opinions and aspirations of the community and regulating them in such a way that they can accumulate to get a conclusion as a consideration in government. It also has a function as a means of regulating conflict, which is interpreted as a manager of conflicts that occur in the community (Budiardjo, 1981). In addition to having a function, political parties also have obligations, as confirmed in Article 13 of Law Number 2 of 2008, as amended by Law Number 2 of 2011, the formulation of which is to practicing Pancasila, implementing the 1945 Constitution of the Republic of Indonesia, and legislation; maintaining the integrity of the Republic of Indonesia; participating in national development; upholding the supremacy of law, democracy and human rights; conducting political education and channel the political aspirations of its members; successful holding of elections; registering and maintaining member data order; maintaining a list of contributors and the amount of donations received, and be open to the public; submitting accountability reports on financial revenues and expenditures sourced from the State Budget and Regional Budget and Regional Budget in the form of 1 (one) yearly to the government after being raped by the Supreme Audit Board; having a special election campaign fund 
account; and socializing political party programs to the public.

To support every function possessed by each political party, a format is made so that political parties can have representatives in the DPR. The existence of this representative will later become an extension of the political parties and the DPR. It is because of this elected representative who will later voice various aspirations from the political parties that carry it. This process is then referred to as political representation.

Alfred De Grazie defines representation (representation) as the relationship between two representatives and the party they represent (constituents). In this case, the deputy holds the authority to carry out several actions that have the approval of his constituents. In line with this opinion, Hanna Penicle Pitkin defines representation as a process of representing, in which the representative acts to react to the interests of the party being represented. Representatives act in such a way that there is no conflict between representatives and those represented, and if that happens, then it must be resolved through an explanation. Representation is the concept that a person or group of people has the ability or obligation to speak and act on behalf of a larger group.

To carry out the duties assigned represented, each representative must meet certain classifications that will ensure the implementation of the representative function. In addition to obtaining status as a representative, the candidate nominally must take several procedures that will guarantee his validity as a representative. Each representative must be required to have the ability or expertise expected or expected to be utilized to serve the tasks of the representative. Because the fertilization of excess capacity is related to the resources that are owned or can be utilized, then often people who have resources are seen as appropriate representatives. Principally, each representative certainly sees himself as representing citizens who are within the scope of his representation whole. Therefore, representatives are referred to as people's representatives. However, in its implementation, it is very difficult to carry out the overall interests and needs represented (Surohmat, 2000). Representative attention to representation can be done in three ways, namely: giving group attention, paying attention to the party, and paying attention to the regions or regions represented. Focusing on groups and parties is also referred to by Heinz Eulau as a regionally focused representative (Surohmat, 2000).

\section{RELATIONSHIP OF MEMBERSHIP OF POLITICAL PARTIES AND PARLIAMENT IN THE CONTEXT OF LAWS AND REGULATIONS}

The focus of representation on groups is the choices available relating to the nature of pluralistic society. Society is grouped on tradition, regionalism, race, language, religion, livelihood or economy, and so on. Here the representative serves as a benchmark for decisions that will be supported or taken. This means that in determining the attitude towards the problem at hand, the representative can focus on the opinions, aspirations, interests, or demands of one or several groups that he considers appropriate and by the situation or situation. The focus of attention on the party must be chosen by the representatives to facilitate the organization of their tasks because through this focus the representatives are simultaneously acting for two parties, namely the party as a political organization that has the merit of supporting the representative and the people who sympathize, support or become members of the party concerned. For all this, the representatives only need to pay attention to the party that is dominating, and fighting for the position of people's representative. The focus on the region is very closely related to the regional representation. In this case, representatives see units represented by region so that attention can be given to the nation, state, province, district, and so on (Surohmat, 2000).

Representative institutions in a democratic country must be arranged in such a way as to be able to provide representation to the people optimally and responsibly. Given CF. Strong, as quoted by Miriam Budiardjo (1981), said that democracy is a system of government in which the majority of adult members of the political community participate based on a system of representation that guarantees that the government is ultimately accountable for its actions to the majority.

In Arbi Sanit's (1985) view, representative institutions have a political representation function, in which the legislative body or representative institutions make policies on behalf of community members who are overall represented in these institutions. In this case the legislative body or the people's representative institutions act as protectors of the interests and channel the aspirations of the people they represent.

Based on a theoretical study of the analysis and views of political thinkers, there are some basic concepts of representation that generally occur. Some of these important concepts, namely delegated representation, where a representative is interpreted as 
a spokesperson on behalf of the group he represents. As such, a representative may not act outside the authority that mandates. While party representation, individuals in representative institutions are representatives of the political parties they represent. Increasing party organization and discipline encourages the birth of party bosses and party caucuses. Representatives in representative institutions become representatives of the organizations / political parties concerned (Pito et al., 2006).

To maintain good relations between representatives and those representing them, it is necessary to establish political communication. In a political process, all functions in the political system, both political socialization and recruitment, articulation of interests, aggregation of interests, making rules, applying rules, and judging rules, are all demonstrated through means of communication (Karim, 2007). The function of political parties as a means of political communication requires political parties to channel a variety of opinions that exist in society. This shows the amount of responsibility held by political parties. However, aside from these great responsibilities, political parties also have enormous authority.

Political parties have been given the right to make policies that concern the lives of many people, namely through policies or decisions that are binding on all citizens, so it needs a balance between the rights and obligations that have been held by political parties. The balance between rights and obligations can be done ideally with the establishment of a good system in the internal political parties. The system certainly includes communication that must be built between political parties and their members of parliament in parliament who make policies on behalf of the people.

The function of political communication requires that political parties as much as possible be able to capture the aspirations of the people in their respective ways that are considered most appropriate. Without a proper system to accommodate the people's aspirations, political parties can be judged to have failed in carrying out the mandate given by the constitution. The amount of authority possessed by political parties can also be seen in the interim termination process (PAW) of a board member. Article 239 Paragraph (2) of Law Number 2 of 2018 concerning the Second Amendment to Law Number 17 of 2014 concerning the MPR, DPR, DPD, and DPRD, emphasizes that members of the People's Legislative Assembly stop because of die, resigning or being terminated. Moreover, members of the People's Legislative Assembly are dismissed between times as referred to in paragraph (1) letter $\mathrm{c}$ if s/he is not able to carry out tasks in a sustainable or unable to remain as a member of Parliament for 3 (three) consecutive months without any information; violates oath/promise of position and code of ethics; being declared guilty based on a court decision that has obtained permanent legal force due to a criminal act that is threatened with imprisonment for 5 (five) years or more; proposed by political parties by statutory provisions; no longer fulfilling the requirements as a candidate for DPR member by the provisions of the legislation regarding the general election of members of DPR, DPD, and DPRD; violates the prohibition provisions as regulated in this law; dismissed as a member of a political party following statutory provisions, or became a member of a political party.

Substitution between the time proposed by political parties to their members in the DPR shows that the position and role of political parties are more dominant than the people who voted for it. This is what often disrupts the performance of the DPR in fighting for various people's aspirations because for this case DPR members must get the blessing of the political parties that carry it. The pattern of interchange between the time that gives room for political parties to dismiss their members as party members that have an impact on their membership status in the DPR shows that political parties have failed internally to show themselves as democratic parties. The great authority possessed by political parties will be very influential in every action of DPR members who tend to impose the will of political party leaders on their members. Even if they disagree with the opinion of the political parties that carry it, their careers in the world of politics are threatened. This is what gives birth to the concept of oligarchic power. It is said as an oligarchy because the monopoly of power is in the hands of its leaders. The role of DPR members in every political decision-making is very large. However, before this decision is taken, members of the DPR must follow everything that has been decided inside the internal political party.

This political attitude which has been determined by each political party must then be carried out by members of the DPR. This fact shows that there is an unhealthy process of democratization in the political system in Indonesia, especially in the system of representation. The phenomenon that a member of the People's Legislative Assembly cannot freely act following the aspirations of the constituents is evidence 
that a member of the People's Legislative Assembly who is given the responsibility to voice the aspirations of the people no longer has a strong position in carrying out this task. In this context, Meisburger (2012) states that strengthening democracy is an important part of national development in an Asian country. Hassall n \& Saunders (2007) stated that supervision is needed to strengthen the accountability function in strengthening democracy in the Asia Pacific. Rahman (2007) also emphasizes the important function of electoral democracy to get people's representatives who aspire to the interests of the people. Finally, Ridhahani (2017) proposes a strategy for developing empathy values for female parliamentarians in Malaysia to get constituent support.

\section{CONCLUSIONS}

The relationship between the people, political parties, and the DPR as a legal representative body of the people is strictly regulated, both in the 1945 Constitution of the Republic of Indonesia and in the form of other laws and regulations. The arrangement that was formed in connection with the pattern of political representation relations between the people, political parties, and the DPR shows that there are arrangements that prioritize the interests of political parties that carry their members to sit in the DPR's institutions, rather than the interests of DPR members as people's representatives.

The implications of these non-aspirational legal products also affect the exercise of people's sovereignty. Members of political parties integrated into the DPR who are supposed to be representatives of all the people of Indonesia, and are expected to be able to implement various people's aspirations, are shackled by the interests of political parties. Such a condition naturally results in the shifting of people's sovereignty to the sovereignty of political parties.

In connection with this, the actual existence of the DPR as the executor of people's sovereignty can be realized if its membership is no longer affiliated with political parties. This means that members of the DPR who have been elected in general elections must be free from political party intervention. After being elected, the member of the DPR concerned must be separated from the political parties that carry him. The existence of factions that greatly affect the existence of the DPR as implementing the sovereignty of the people must also be eliminated, so that elected DPR members can be professional in carrying out their functions.

\section{REFERENCES}

Bünte, M., \& Ufen, A. (2008). The New Order and its legacy: Reflections on democratization in Indonesia. In Democratization in Post-Suharto Indonesia (pp. 23-50). Routledge. https://doi.org/10.4324/9780203934760

Hassall, G., \& Saunders, C. (2007). Asia-Pacific constitutional systems. Cambridge University Press.

Karim, Z. A. (2007). Komunikasi Politik: Konsep, Model dan Pendekatan. Modul Kuliah tidak diterbitkan, Sekolah Tinggi IImu Sosial dan IImu Politik Tanjungpinang.

Kitschelt, H. (2000). Linkages between citizens and politicians in democratic polities. Comparative political studies, 33(6-7), 845-879. https://doi.org/10.1177/001041400003300607

Meisburger, T. (2012). Strengthening democracy in Bangladesh. The Asia Foundation.

Merkl, P. H., \& Lawson, K. (Eds.). (1988). When Parties Fail: Emerging Alternative Organizations. Princeton University Press.

Pito, T. A., Efriza, Fasyah, K., \& Piliang, I. J. (2006). Mengenal teori-teori politik: dari sistem politik sampai korupsi. Nusa Cendekia.

Pradityo, R. (2018). Penyelesaian Perselisihan Internal Partai Politik Secara Mufakat Dan Demokratis/Dispute Resolution Of Internal Political Parties In Consensus And Democratic. Jurnal Hukum dan Peradilan, 7(3), 375-386.

https://doi.org/10.25216/JHP.7.3.2018.375-386

Rahman, T. (2007). Parliamentary control and government accountability in South Asia: A comparative analysis of Bangladesh, India and Sri Lanka (Vol. 6). Routledge. https://doi.org/10.4324/9780203945766

Ridhahani. (2017). Strategies of female members of parliament in developing empathy values to gain constituent support. Citizenship, Social and Economics Education, 16(2), 132-142. https://doi.org/10.1177/2047173417712679

Sanit, A. (1985). Perwakilan politik di Indonesia. Rajawali.

Stokke, K., \& Törnquist, O. (2013). Paradigmatic failures of transformative democratic politics: Indonesia and Sri Lanka in comparative perspective. In Democratization in the Global South (pp. 100-124). Palgrave Macmillan, London. https://doi.org/10.1057/9780230370043 5

Strong CF. in Budiardjo, M. (Ed.). (1981). Partisipasi dan partai politik: sebuah bunga rampai. Penerbit PT Gramedia.

Surohmat. (2000). Fungsi Pengawasan DPR Sebagai Kontrol Masyarakat Terhadap Penyelenggaraan Pemerintahan, Jurnal Hukum, 1(1), 5051.

Ulum, M. B. (2019). How Democracy is Election? Reassessing Article 18 (4) of the 1945 Constitution and its Implication to the Regional Head Election in Indonesia. Jurnal Hukum dan Peradilan, 8(2), 315-332. https://doi.org/10.25216/JHP.8.2.2019.315-332

(c) 2021 Cahyawati and Hoesein; Licensee Lifescience Global.

This is an open access article licensed under the terms of the Creative Commons Attribution Non-Commercial License (http://creativecommons.org/licenses/by-nc/3.0/) which permits unrestricted, non-commercial use, distribution and reproduction in any medium, provided the work is properly cited. 